\title{
Nontraditional Use of Biomass at Certified Forest Management Units: Forest Biomass for Energy Production and Carbon Emissions Reduction in Indonesia
}

\author{
Asep S. Suntana, ${ }^{1,2}$ Kristiina A. Vogt, ${ }^{1,3,4}$ Eric C. Turnblom, ${ }^{5}$ \\ Daniel J. Vogt, ${ }^{1}$ and Ravindra S. Upadhye ${ }^{6,7}$ \\ ${ }^{1}$ Forest Systems and Bio-Energy Program, School of Environmental and Forest Sciences, College of the Environment, \\ University of Washington, P.O. Box 352100, Seattle, WA 98195-2100, USA \\ ${ }^{2}$ RMI, The Indonesian Institute for Forest and Environment, Jalan Sempur No. 55, Bogor 16154, Indonesia \\ ${ }^{3}$ Interforest LLC, Holderness, NH 03245, USA \\ ${ }^{4}$ Renewol LLC, 63260 Overtree Road, Bend, OR 97701, USA \\ ${ }^{5}$ Forest Biometrics Program, School of Environmental and Forest Sciences, College of the Environment, University of Washington, \\ Box 352100, Seattle, WA 98195-2100, USA \\ ${ }^{6}$ ARU Associates, Pleasanton, CA 94566, USA \\ ${ }^{7}$ Department of Chemical and Biomolecular Engineering, University of California, 201 Gilman Hall, Berkeley, CA 94720-1462, USA
}

Correspondence should be addressed to Asep S. Suntana, asuntana@uw.edu

Received 2 November 2011; Revised 15 March 2012; Accepted 27 March 2012

Academic Editor: David B. DeVallance

Copyright ( $) 2012$ Asep S. Suntana et al. This is an open access article distributed under the Creative Commons Attribution License, which permits unrestricted use, distribution, and reproduction in any medium, provided the original work is properly cited.

\begin{abstract}
Biomass conversion technologies that produce energy and reduce carbon emissions have become more feasible to develop. This paper analyzes the potential of converting biomass into biomethanol at forest management units experiencing three forest management practices (community-based forest management (CBFM), plantation forest (PF), and natural production forest (NPF)). Dry aboveground biomass collected varied considerably: $0.26-2.16 \mathrm{Mg} / \mathrm{ha}$ /year (CBFM), $8.08-8.35 \mathrm{Mg} / \mathrm{ha} / \mathrm{year}$ (NPF), and $36.48-63.55 \mathrm{Mg} / \mathrm{ha} /$ year (PF). If $5 \%$ of the biomass was shifted to produce biomethanol for electricity production, the NPF and PF could provide continuous power to 138 and 2,762 households, respectively. Dedicating 5\% of the biomass was not a viable option from one CBFM unit. However, if all biomasses were converted, the CBFM could provide electricity to 19-27 households. If $100 \%$ biomass from two selected PF was dedicated to biomethanol production: (1) 52,200-72,600 households could be provided electricity for one year; (2) 142-285\% of the electricity demand in Jambi province could be satisfied; (3) all gasoline consumed in Jambi, in 2009, would be replaced. The net carbon emissions avoided could vary from 323 to $8,503 \mathrm{Mg}$ when biomethanol was substituted for the natural gas methanol in fuel cells and from 294 to 7,730 Mg when it was used as a gasoline substitute.
\end{abstract}

\section{Introduction}

Indonesia's demand for energy is high and the in-country supplies are not currently sufficient to satisfy these requirements. According to the Oil and Gas Journal, as cited by the U S A Energy Information Administration [1], Indonesia has the equivalent of about 620 billion cubic meters ( 3.9 billion barrels) of proven oil reserves and 3 trillion cubic meters (97.8 trillion cubic feet) of natural gas. Since 1996, however, Indonesia's total oil production has dropped by 35 percent
[1]. Yet $63 \%$ of Indonesian energy consumption and economic growth continues to be based on consuming oil [2].

Furthermore, Indonesia is mostly dependent on its own fossil energy supplies in global markets to generate income; $27.2 \%$ of the Indonesian government's 2008 budget was generated from taxable and nontaxable revenues derived from in-country supplies of oil, gas, and minerals [3]. At the same time, Indonesia must continually extract or import more oil to satisfy its current oil demand as well as to power new development projects. The rising prices of international 
fossil fuel supplies has forced the government of Indonesia to raise fossil fuel prices by 29 percent in March of 2005 and by another 114 percent in October of the same year [4]. This situation means that Indonesia has to explore the production of alternative energy resources to satisfy local in-country demand for energy. Energy consumption in Indonesia is projected to increase by 2.9 percent per year during the next 20 years due to the growth of both its economy and its population [2]. Approximately 40 percent of this increased energy demand is projected to occur in the industrial sector, followed by the residential ( 29 percent), transportation ( 28 percent), and commercial (3 percent) sectors [5].

It is challenging for Indonesia to acquire these new supplies of energy because increasing the extraction levels of any energy supply will have to address concerns regarding environmental and social issues. For example, expansion of coal, oil, and gas exploitation is a less viable option because it could seriously threaten the territories and livelihoods of indigenous peoples in Indonesia [6]. Furthermore, there is a strong reluctance to develop and use nuclear energy. Indonesia therefore has few alternative options that would satisfy the energy demand of its growing economy. At the same time, any energy option selected by Indonesia has to simultaneously address: (1) how much greenhouse gases are emitted during the combustion of any selected energy source since Indonesia is ranked as the third highest emitter of GHG due to land use and land use change in forestry; (2) the potential of production of the energy to contribute to local/regional economic revitalization of communities.

Agricultural- and/or forestry-based bioenergy programs are now being considered as viable alternative approaches to produce energy. These resources are abundant in the regions of Indonesia that lack energy security and they can be designed to significantly reduce GHG emissions when they substitute for fossil energy sources. Bioenergy also has the potential to be environmentally sustainable, economically viable, and socially and politically acceptable. Furthermore, most of forest management units are located in remote areas of Indonesia where the electrical grid and fossil fuel supplies are not always available and where it is too expensive to build the infrastructure to deliver the needed energy. This situation has also stifled regional economic development since managers of forest operations and small wood industries (e.g., sawmill and wood working) are finding it difficult to meet their production targets because of fossil fuel shortages. Even local communities and indigenous peoples that collect nonwood products (e.g., rattan, honey, and Tengkawang' fruits (Shorea spp)) are facing difficulties in transporting their products to markets due to energy shortages.

There are four major strategies available to mitigate carbon emission through forest-based activities: (1) increase forested land area through reforestation; (2) increase the carbon density of existing forests at both the stand and landscape scales; (3) expand the use of forest products that sustainably replace fossil-fuel $\mathrm{CO}_{2}$ (or carbon) emissions, (4) reduce emissions derived from deforestation and forest degradation [7]. These strategies are in line with most countries' policies regarding their biomass energy programs, that is, energy production and mitigating greenhouse gas (GHG) emissions [8-13]. This being the case, there is a need to determine whether sufficient biomass exists to economically replace fossil fuel use and whether this use will avoid carbon emissions so that it qualifies for carbon or renewable energy credits. With the use of today's technology to efficiently convert forest biomass into biomethanol, the annual amount of forest wastes generated throughout Indonesia has the potential to produce over 40 billion liters of methanol each year [14]. If this higher conversion efficiency potential is possible based on the chemical quality of trees found in Indonesia, this amount of methanol fed into fuel cells would be able to produce sufficient electricity on a continuous basis to power 10,063 million households while significantly reducing Indonesian net carbon emissions $(\sim 29.48 \mathrm{Tg}$ of avoided carbon emission [14]).

These country-level estimates suggest that using forest wastes is a viable option for the Indonesia's landscape, nevertheless, these country-level potentials need to be verified at the level of a forest management unit. It is at this level where bioenergy production can be evaluated to determine which parts of forest landscape matrix can be sustainable used to collect forest materials suitable for new energy products. Since forests are not managed at the same intensity across the Indonesia's landscape, forest being intensively managed should be able to generate additional biomass wastes and therefore more alternative energy products. Unmanaged forests may be less suitable for these purposes. Currently, several forest management operations and small forest industries have expressed interest in increasing their energy production potential from their forests. If the development of new energy products from forest wastes is going to become a viable option, however, local forest managers will have to demonstrate that they can collect a sufficient amount of waste materials and still maintain their forest certification status.

Clean energy produced from locally harvested biomass could alleviate these energy shortages and provide alternative economic activity for rural community members living in or adjacent to forests. Converting biomass to methanol and substituting it for fossil-fuel-based energy production is one viable option in locations that generate high biomass waste supplies $[8,15,16]$. Building biofuel production capacity is ideal products to generate in Indonesia because it can be produced in a distributed manner by local community members and can satisfy several different energy needs. For example, it can be readily blended with gasoline and can be distributed to customers without the need to develop additional distribution infrastructures. Hydrogen fuels, on the other hand, would require new engine designs and additional infrastructure that would create the immediate need for large financial investments [17]. As an added incentive, green fuels from cellulosic or lignin-based biomass produce lower emissions of greenhouse gases and atmospheric pollutants when compared to gasoline produced from fossil fuels [17-19].

Recent technological developments in the energy sector (e.g., gasifiers more efficient in converting wet biomass to bio-oils or fuel oils, and hydrogen fuel cells $[16,20-25]$ ) are creating alternative opportunities to produce energy locally to alleviate fuel shortages. Using wood wastes to 
produce biofuels rather than using agricultural wastes is ideal because wood has a chemistry that results in higher efficiencies of conversion to biofuels [8]. Although the chemical composition of wood varies among tree species [26], wood is a more efficient and reliable starting material to produce methanol compared to other nonwood biomass sources [27]. Furthermore, extensive areas of forests that exist that need to be managed to remove woody debris wastes and to remove invasive species to restore forest health (e.g., reduce fire risk). Much of this biomass has little economic value today so promoting its conversion to biofuels adds value to forest waste materials and can reduce local "environmental and energy insecurity" [28].

Past technologies to convert biomass into gases or liquid coproducts were not considered economical except when these facilities were large scale and centralized $[15,29]$. Large scale facilities are expensive to build. They also face significant distribution challenges due to the need to transport wood from beyond an economically viable transportation network. This is a less viable option for rural communities. Today, development of decentralized facilities that consume local or regional resources [8] is becoming a more viable option due to environmental and human health concerns related to consuming traditional energy supplies, energy security issues, and the higher costs of buying fossil fuels. In fact, local energy production can simultaneously contribute to developing sustainable livelihoods for rural communities, consume abundant local biomass resources to build decentralized energy production systems, stimulate sustainable development, and help to mitigate climate change.

It is important to determine how much additional regional energy can be generated from forests wastes and how this varies across forest management types. The objective of the study is to explore how (1) the amount of forest biomass wastes generated varies between less intensively managed forests (e.g., community-based forest management units) and moderately to intensively managed forests, that is, plantations or managed natural forests, and (2) how much biomethanol can be produced from the available biomass wastes and how much electricity it can generate or contribute to alleviate local transportation fuel demand. This study was not designed to contribute to an Indonesian market and policy-level analysis of forest bioenergy production but to determine the potential for expanding regional energy production and determine how different forest management types influence which forest management units should have their energy capacity developed further.

\section{Research and Calculation Methods}

2.1. Forest Management Units Types. Most of the woody biomasses harvested in Indonesia are collected from three different forest management types: community-based forest management (CBFM) units with the lowest management inputs, natural production forests (NPF) with intermediate levels of management input, and plantation forests $(\mathrm{PF})$ which receive the highest intensity of management input. Management units selected for this study were all certified as being sustainably managed forests under the aegis of the Indonesian Ecolabelling Institute (LEI) forest certification system. LEI system includes three different forest management certification schemes, namely, NPF, PF, and CBFM certification. Since sustainability of forest management requires that biomass is harvested from a sustainably managed forest (as stated in certificates of their forest performances), this study only includes those forests designated primarily for the production of wood fiber, bioenergy, and/or nonwood forest products, that is, production forests [30].

Although the International Tropical Timber Organization/ITTO [30] divides permanent forest estates into two categories, natural production forest (NPF) and planted forests $(\mathrm{PF})$, this study assessed three forest management types. This study included a category of timber production from forest that is managed by rural and indigenous community members, that is, community-based forest management (CBFM).

Large forest concession holders that manage both NPF and PF control 35.5 million hectares or $71 \%$ of the total production forest in Indonesia [31]. Of the total production forests that are managed under the concessionaires system, 26.6 million ha are managed under the natural production forest (NPF) system approach (harvesting is done using a selective cutting system) and the timber harvested is mostly consumed by the plywood industry [31]. Plantation forests $(\mathrm{PF})$ or timber plantation are developed either independently of, or in association with, existing natural forest production concessionaires [32]. Plantation forest management protocols are based on clear cutting practices. These timber supplies are consumed by either the pulp and paper or wood construction industries. Among various definitions, community-based forest management (CBFM) can be defined as a variety of forest resources management practices developed by local community members living in or in the surrounding forest areas [33]. Most CBFM do not apply intensive forest management system practices and typically do not have a written forest management and harvesting plan. The timber harvested is mostly consumed by the sawmill and woodworking industries in the region where the CBFM areas are located.

2.2. Forest Management Units Included in This Study. Forest biomass data were derived from several sources: the forest certification assessment reports conducted under the auspices of Lembaga Ekolabel Indonesia (LEI) and various other reliable sources (e.g., data directly submitted by the certified forest management units). Data were collated and summarized for the six certified forest management units included in this study and are nested in three different forest management types: NPF, PF, and NPF (Figure 1).

For this study, the community managed forests are abbreviated as CBFM-1 and CBFM-2; CBFM-1 manages 1,179 ha of forest land in the Sukoharjo district and CBFM-2 manages 2,434 ha of forest land in the Wonogiri district. Both forests are located in Central Java province. The certified NPF unit number 1 (NPF-1) is located in Rokan Hilir district in Riau province and consists of 90,956 ha of managed forest, and NPF-2 manages 269,660 ha of forest in the Kutai Barat district in East Kalimantan province. The certified PF units 


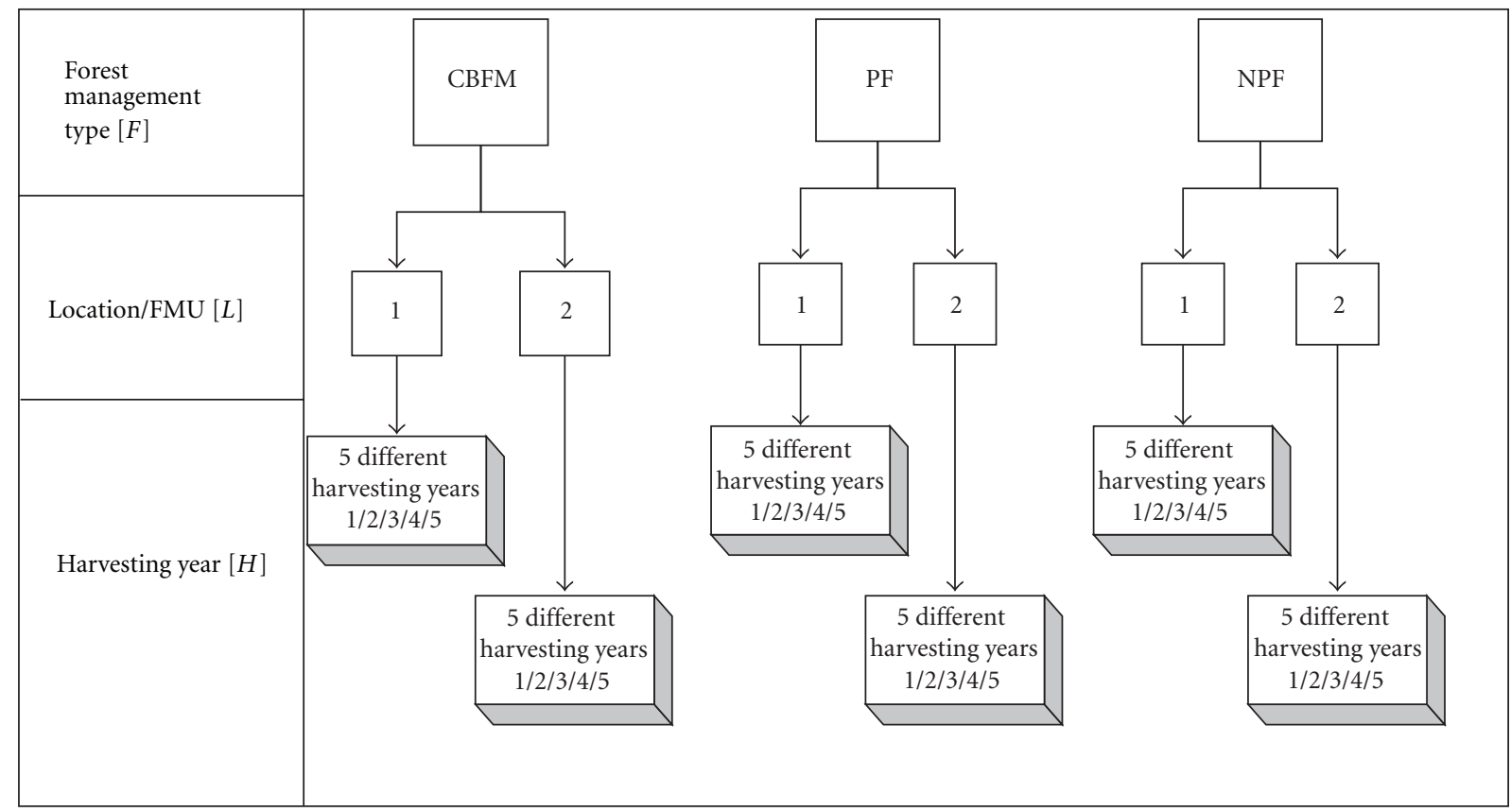

FIGURE 1: Research design for the forest biomass data collected from the certified forest management units nested in different forest management types and based on five separate years of data collection. Note: CBFM: Community-Based Forest Management; NPF: Natural Production Forest, and; PF: Plantation Forest.

are located in the Kampar district in the Riau province (PF1) and Tanjung Jabung Timur in the Jambi province (PF-2); PF- 1 manages 235,140 ha of forest land and PF-2 manages 293,812 ha of forest lands.

Except for the plantation forests that can be dedicated entirely for energy production (energy farm), not all of the available forest biomass can be used to produce energy because of alternative or competitive uses. Certain forest industries may have a higher rate of return from alternative uses and therefore provide limited opportunities for biomethanol production, for example, teak (Tectona grandis) plantations that are managed by CBFM practitioners (forest farmers group) and state-owned companies. For the calculations conducted here, a conservative five percent of aboveground forest biomass was assumed to be available each year from each forest management type; this collection level is based on ecological criteria and represents the annual growth or productivity of a natural forest. Natural production forests management units could generate $22 \%$ wastes from their forest operations [34] so the five percent used in this study is a very realistic and conservative figure.

Calculations are based on the output of the energy produced and do not include the inputs since this information is confidential company data and was unavailable for this study. Since waste wood methanol has a default greenhouse gas emissions savings of $94 \%$ [35], focusing on the output can be used for comparative purposes to determine how the intensity of management affects the potential amount of energy coproducts that can be produced by each forest management unit.
2.3. Management Unit Level Calculations: Biomass Conversion to Methanol and Coproducts. All calculations were conducted at the forest management unit (FMU) level using information collected at each site. The five-year average aboveground biomass collected at the FMU level was used in the calculations for the quantity of methanol that could be produced from each management unit.

Calculations were scaled up to the FMU level with assumptions of the efficiency of converting a dry metric ton of biomass into methanol [10]. This conversion efficiency was developed for a small-scale mobile facility where methanol (high energy density) is being transported from the forest instead of wood (a high mass density material but of a low energy density). For the purposes of this study, an extraction efficiency of $50 \%$ was assumed when converting wood wastes to methanol. The efficiency of methanol production from wood has been reported to vary between 45 to $57 \%$ based on the technology and the chemistry of the wood $[8,27,36]$. For this study, all results were based on the same units of measurement, either $1 \mathrm{MWh}$ of electrical energy produced or $1 \mathrm{Mg}$ of dry biomass was used.

The amount of carbon emissions avoided were estimated by determining the amount of energy produced from $1 \mathrm{Mg}$ of dry biomass and then using the estimate of carbon emitted when producing the equivalent amount of energy using a nonrenewable resource. One dry $\mathrm{Mg}$ of biomass produces $630 \mathrm{~L}$ of biomethanol when the conversion efficiency is $50 \%$ based on Perry's Chemical Engineers Handbook [37]. Substituting the biomethanol derived from $1 \mathrm{Mg}$ dry biomass (with extraction efficiencies of 50\%) for natural 
gas-derived methanol used for electricity production would avoid carbon emissions equivalent to $462 \mathrm{~kg}$ carbon. Substituting biomethanol derived from $1 \mathrm{Mg}$ dry biomass (with extraction efficiencies of 50\%) for gasoline is substituted would avoid carbon emissions equivalent to $420 \mathrm{~kg}$ carbon. In our study, the estimates of carbon emissions avoided are conservative since: (1) waste-wood methanol has a lower $\mathrm{CO}_{2}$ emissions during cultivation, processing, transport, and distribution compared to other biomass derived fuels [35], and (2) $\mathrm{CO}_{2}$ emissions from the procurement, shipping, and processing of gasoline and natural gas were not considered.

The carbon emissions avoided were then calculated when using biomethanol as a substitute for gasoline or replacing an energy-equivalent amount of natural gas methanol in fuel cells to produce electricity. In estimating carbon emissions, fuel cells powered by biomethanol were compared to fuel cells using natural gas-methanol since most of the methanol today is derived from natural gas [38]. For scenarios using biomethanol as a gasoline substitute, 100\% substitution of gasoline in regular motor vehicles was assumed even though there is a range of methanol/gasoline mixtures in use. Currently, M85, a fuel mixture consisting of $85 \%$ methanol mixed with 15\% unleaded gasoline, or lower blends are commonly discussed and are already being used in fleet vehicles. Hasegawa et al. [39] mentioned that several hundred methanol vehicles that use neat methanol (M100) were manufactured as low-emission vehicles in Japan.

It was assumed that gasoline (representing fossil fuels) would be substituted by an equal volume of biomethanol even though it is well known that gasoline by volume has more energy produced per equivalent volume of methanol. Many factors will determine the efficiency at which machineries and/or vehicles burn fuels [39, 40]. The total amount of fossil fuels and electricity consumed in: (a) Asia Pulp and Paper (APP) industry and (b) Jambi province were used to calculate possible carbon emissions reduction in this paper. Since many of the district and provincial governments do not publish data on gasoline consumptions and carbon emissions, site specific data the forest management unit level could not be calculated.

2.4. Statistical Model and Assumptions. The statistical model used in this study was designed to consider that data shown in Table 1 from each FMU as a random factor. The following considerations explain the model: (1) the research does not have any intention to control the experimental population, so randomization happens during the experiment, (2) the list of certified FMUs is published by the Indonesian Ecolabeling Institute (LEI), and (3) although there is a narrow certified FMU population, the research experimental design is still random as they represent an uncontrolled selection from total management units that were available for this research.

In this study, the statistical model was:

$$
\begin{gathered}
y_{i j k}=\mu+F_{i}+(L)_{j(i)}+(e)_{k(i j)}, \\
i=1, \ldots, 3 ; \quad j=1,2, \ldots, 6 ; \quad k=1,2, \ldots, 5, \ldots,
\end{gathered}
$$

where $y_{i j k}$ is the amount of aboveground commercial biomass of timber by $k$ th harvesting year in the $j$ th location/
FMU in the $i$ th forest management type, $\mu$ is the overall mean of aboveground commercial biomass of timber, $F_{i}$ is the fixed effect of the $i$ th forest management type, $(L)_{j(i)}$ is the random effect of the $j$ th randomly selected location/FMU nested within $i$ th forest management type, $(e)_{k(i j)}$ is the random error, and $(L)_{j(i)}$ are i.i.d. as $N\left(0, \sigma_{L(F)}^{2}\right),(e)_{k(i j)}$ is i.i.d. as $N\left(0, \sigma^{2}\right)$, and $(L)_{j(i)},(e)_{k(i j)}$ are mutually independent.

\section{Result and Discussion}

3.1. Biomass Harvested from CBFM, PF, and NPF. All the data were collected from certified FMUs that are nested in the certified CBFM, PF, and NPF. For each management unit, the average aboveground biomass value for the total commercial harvest of forest biomass was used when calculating the amount of biomethanol that could be produced. The quantity of commercial forest biomass (timber) that was harvested each year within a five-year period (2001-2005) from six certified forest management units (FMUs) can be found in Table 1.

Analysis of variance (ANOVA) indicates that significant differences occurred between the average production of commercial biomass per hectare per year by forest management type (CBFM, PF, and NPF). These data suggest that the highest amount of biomass could be harvested from the PF and the least amount from CBFM.

Based on the statistical calculations, data fulfills the normality assumption of the research. The tail of the normal curve is quite heavy (Figure 2); however, this does not alter the mean of the data but does increase its variances. Since field-collected data are typically not normally distributed, these data need to be transformed (such as log transformation) to correct for data distributional problems or data outliers [41, 42]. For this study, this transformation did provide a reasonable inference when the data varied from the assumptions especially since the data sets were not too large [42]. Data from this study resulted in a linear relationship (Figure 3), but this transformation reduced the variance considerably despite the fact that outliers still existed. Since the transformation applied for the whole data, the distributions are the same as the distributions before the transformation [42].

3.2. Biomethanol to Substitute Fossil Fuels in Electricity Production and Gasoline Consumption. Our calculations suggest that it is worthwhile to convert forest biomass harvested from certified forest management units into biomethanol for use in electricity production and also as a gasoline substitute. However, this potential varied considerably depending on the forest management type being evaluated. Since there are 48 types of community-based forest managements systems in Indonesia [43], this study's data may not represent all the possible types of community-based forest managements units.

Some of the differences in forest management unit results from what are the main products harvested from the forest and the land tenure status of the forested lands (whether the land belongs to the national government or forest farmers). 
TABLE 1: Commercial forest biomass harvested from each certified forest management unit between 2001-2005.

\begin{tabular}{|c|c|c|c|c|}
\hline \multirow{2}{*}{ Forest management unit } & \multirow{2}{*}{ Harvesting year } & \multicolumn{3}{|c|}{ Harvested aboveground biomass (Dry) } \\
\hline & & $\mathrm{m}^{3}$ & $\mathrm{Mg}$ & $\mathrm{Mg} / \mathrm{ha}$ \\
\hline \multirow{6}{*}{ CBFM-1 } & 2001 & 573 & 287 & 1.64 \\
\hline & 2002 & 692 & 346 & 1.99 \\
\hline & 2003 & 691 & 345 & 1.98 \\
\hline & 2004 & 894 & 447 & 2.56 \\
\hline & 2005 & 919 & 460 & 2.64 \\
\hline & 2001-2005 average & 754 & 377 & 2.16 \\
\hline \multirow{6}{*}{ CBFM-2 } & 2001 & 235 & 118 & 0.16 \\
\hline & 2002 & 120 & 60 & 0.08 \\
\hline & 2003 & 447 & 224 & 0.30 \\
\hline & 2004 & 469 & 234 & 0.31 \\
\hline & 2005 & 666 & 333 & 0.44 \\
\hline & 2001-2005 average & 387 & 194 & 0.26 \\
\hline \multirow{6}{*}{ NPF-1 } & 2001 & 74,477 & 37,238 & 10.74 \\
\hline & 2002 & 41,635 & 20,818 & 7.49 \\
\hline & 2003 & 46,664 & 23,332 & 6.54 \\
\hline & 2004 & 54,474 & 27,237 & 7.80 \\
\hline & 2005 & 62,373 & 31,186 & 9.17 \\
\hline & 2001-2005 average & 55,925 & 27,962 & 8.35 \\
\hline \multirow{6}{*}{ NPF-2 } & 2001 & 123,642 & 61,821 & 10.52 \\
\hline & 2002 & 49,332 & 24,666 & 3.99 \\
\hline & 2003 & 104,461 & 52,230 & 9.99 \\
\hline & 2004 & 75,193 & 37,597 & 5.82 \\
\hline & 2005 & 104,010 & 52,005 & 10.10 \\
\hline & 2001-2005 average & 91,328 & 45,664 & 8.08 \\
\hline \multirow{6}{*}{ PF-1 } & 2001 & $1,142,794$ & 571,397 & 87.69 \\
\hline & 2002 & 943,421 & 471,711 & 54.26 \\
\hline & 2003 & 125,599 & 627,995 & 56.98 \\
\hline & 2004 & $1,947,206$ & 973,603 & 45.40 \\
\hline & 2005 & $2,072,905$ & $1,036,453$ & 73.44 \\
\hline & 2001-2005 average & $1,246,385$ & 736,232 & 63.55 \\
\hline \multirow{6}{*}{ PF-2 } & 2001 & 851,104 & 203,791 & 37.71 \\
\hline & 2002 & $1,100,960$ & 550,480 & 40.48 \\
\hline & 2003 & 905,416 & 422,117 & 44.01 \\
\hline & 2004 & $1,054,606$ & 532,391 & 22.87 \\
\hline & 2005 & $1,684,171$ & 842,086 & 37.33 \\
\hline & 2001-2005 average & $1,119,251$ & 510,173 & 36.48 \\
\hline
\end{tabular}

For example, CBFM that grows teak (Tectona grandis) on private lands may have different economical consideration than when the forest is managed for subsistence purposes. For this study, data were collected from both CBFM-1 and CBFM-2 which are managed by forest farmers as part of agroforestry systems. Forest farmers manage not only commercial trees, such as teak, mahogany (Swietenia mahagoni), acacia (Acacia auriculiformis), and rain tree (Samanea saman) but also lesser known tree species as well as agricultural plants. Most of forest farmers manage their forests for their long-term benefits, but they also view the forests as instantly cashable bank accounts, such as in tebang butuh or "harvesting for needs" approach $[44,45]$, where forest farmers harvest timber due to immediate family needs for cash. In some areas this approach is changing as commercial interests have now become the main driver for farmers. For example, forest farmers continue to plant trees but now recognize and are even more aware of the true value of their forests [45]. Forest farmers expect to acquire greater economic benefits by becoming certified and combining bioenergy production with traditional forest management practices.

In the community forest management type, harvesting and converting $100 \%$ of the annually available timber into liquid fuels using the tebang butuh management approach have the potential to produce biomethanol quantities capable of generating sufficient electricity to satisfy the demand of 


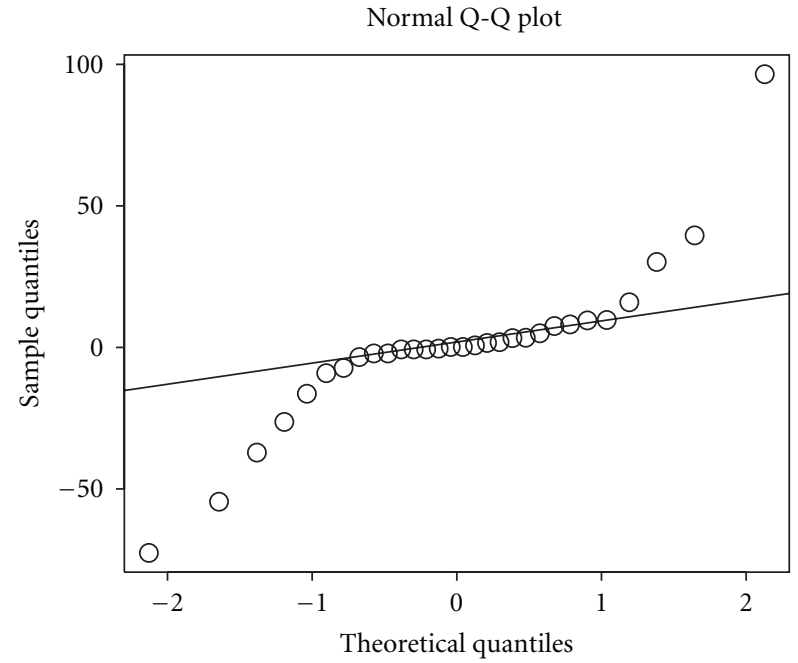

FIgURE 2: Normal Q-Q Plot: comparing research data to a standard normal population.

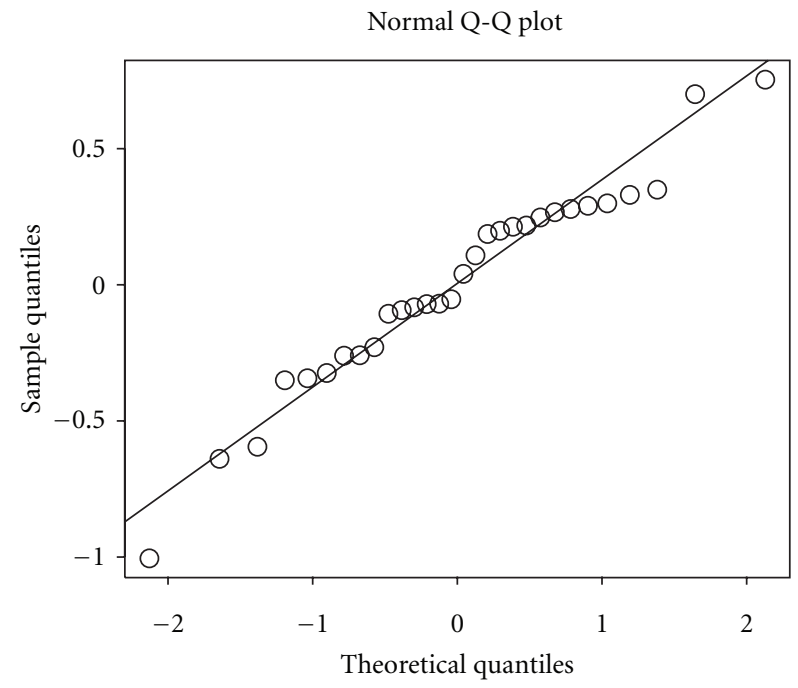

Figure 3: Normal Q-Q plot at logarithmic data.

19 (CBFM-1) to 27 (CBFM-2) households (Figure 4). The differences in the volume of biomass harvested between both of these management units depended solely on the forest farmers' decision on how much to cut. There is no existing regulation that controls the total quantity of timber harvested from these forested lands. Depending on whether $5 \%$ or $100 \%$ of the biomass was collected and converted to biomethanol, the biomethanol production potential varied from 3,050-5,938 or 61,009-118,768 liters, respectively (Figure 4). The potential carbon emissions reduction from using biomethanol to produce electricity varied from 2$4 \mathrm{Mg}$ (5\% of the biomass harvested) and from 45 to $87 \mathrm{Mg}$ (at 100\%). By replacing gasoline as a transportation fuel, the potential reduction in carbon emission varied from 2 $4 \mathrm{Mg}$ and from $41-79$ at a $5 \%$ or a $100 \%$ level of biomass harvesting, respectively.

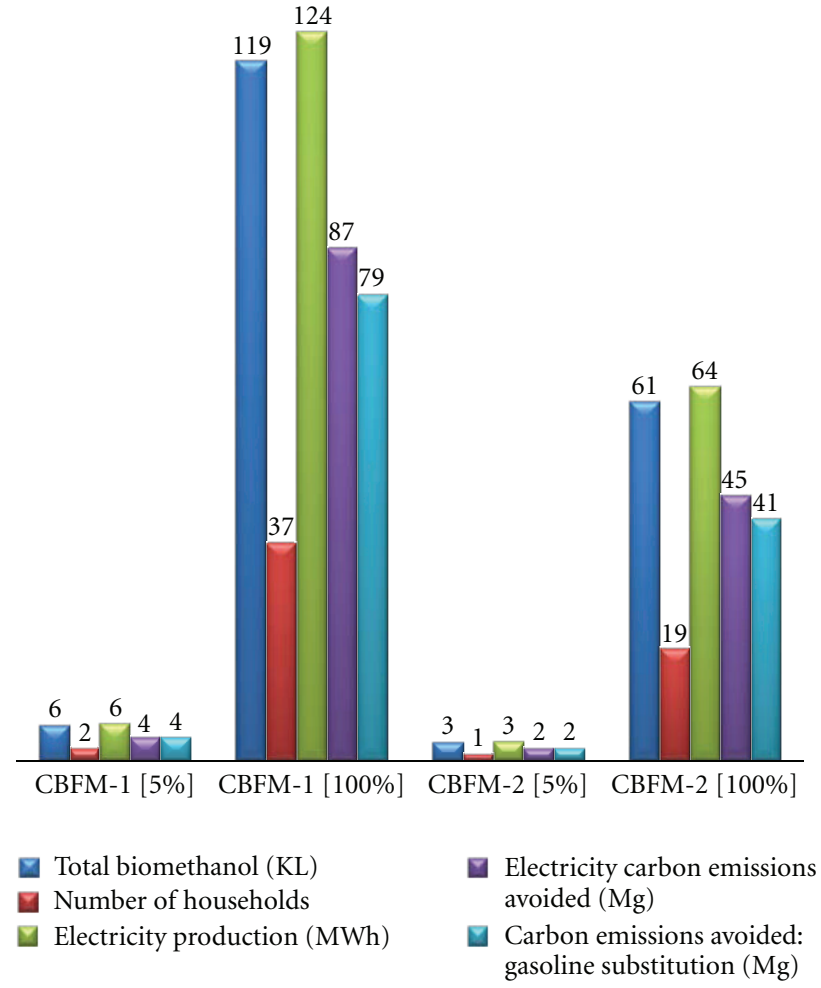

Figure 4: The amount of biomethanol produced and the amount of fossil-resource-derived electricity and gasoline, this amount can potentially replace and avoid carbon emissions when converting 5\% or $100 \%$ of the annually available biomass collected from certified community managed production forests (CBFM).

Where biomass availability is scarce because of high fuel-wood demand or where large areas are degraded as a result of past land uses $[15,46]$, planting fast growing tree species using agroforestry techniques as part of managed reforestation programs may be an effective option to restore these lands while providing socioeconomic benefits and electricity to communities dependent on resource extraction to survive. The villages in Gunung Kidul district, Jogjakarta province as well as in Wonogiri district, Central Java province practice community-based forestry that consists of planting and managing various species of trees. These trees are suitable for use in energy production [26].

Using a decentralized energy planning strategy for the Tumkur district in India, that included a sustainable development scenario, the study has concluded that biomass feedstock harvested from plantations could meet all the electricity needs of the village [47]. The study also stated that the plantation, however, needed a production capacity of $6-8 \mathrm{Mg}$ of biomass per hectare per year, a moderate biomass productivity [47]. This range of biomass production is considerably higher than the production capacity of both the CBFM-1 and CBFM-2 since their average production was $2.16 \mathrm{Mg}$ per hectare per year.

In contrast, this study had much higher forest biomass supplies available from the certified PF-1, PF-2, NPF-1, and NPF-2 forests. In this situation, biomethanol production 
TABLE 2: Total electricity and gasoline consumption at district and provincial levels in Jambi and East Kalimantan (2009).

\begin{tabular}{|c|c|c|c|c|c|c|}
\hline \multirow[t]{2}{*}{ Name of district/province } & \multicolumn{2}{|c|}{$\begin{array}{l}\text { Total electricity consumption by } \\
\text { households (MWh) }\end{array}$} & \multicolumn{2}{|c|}{$\begin{array}{l}\text { Total electricity consumption at } \\
2009 \text { (MWh) }\end{array}$} & \multicolumn{2}{|c|}{ Gasoline consumption (kiloliters) } \\
\hline & District level & Provincial level & District level & Provincial level & District level & Province level \\
\hline Tanjung Jabung Timur, Jambi ${ }^{\mathrm{a}}$ & 13,737 & 394,759 & 18,222 & 643,800 & 4,876 & 282,120 \\
\hline Kutai Barat, East Kalimantan ${ }^{\mathrm{b}}$ & 29,832 & 408,307 & 32,695 & 451,330 & $\mathrm{NA}^{\mathrm{c}}$ & 482,840 \\
\hline
\end{tabular}

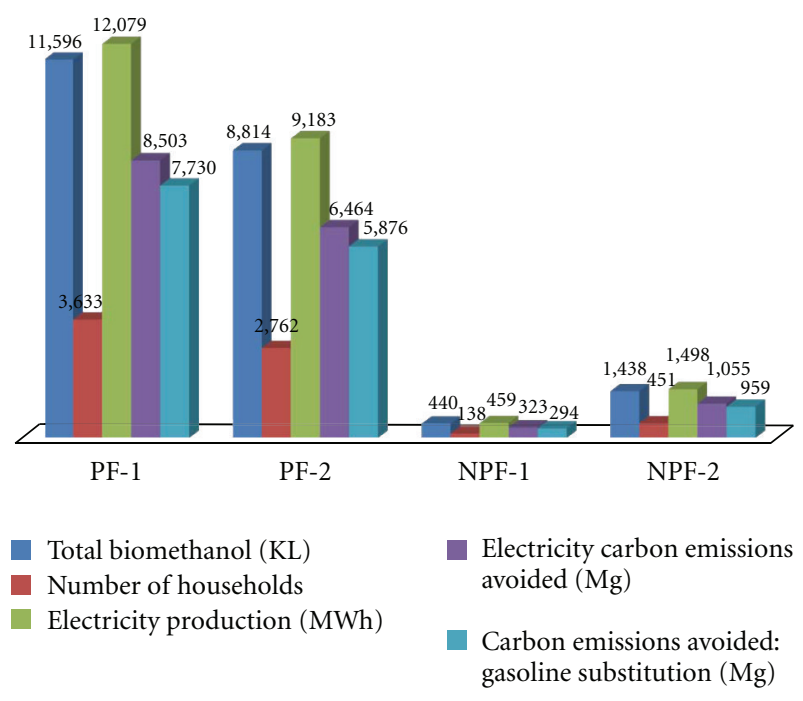

FIGURE 5: The amount of biomethanol produced and the amount of fossil-resource-derived electricity and gasoline, this amount can potentially replace and avoid carbon emissions when converting $5 \%$ of the annually available biomass collected from certified production forests (NPF and PF).

varied from 8,818-11,596 kiloliters in the certified PFs and $440-1,438 \mathrm{KL}$ in the NPFs (Figure 5).

These quantities of biomethanol production would satisfy the electricity demand annually for 2,762-3,633 households using a $1 \mathrm{KW}$ fuel cell powered by biomethanol. The maximum generation of electricity possible would be $12,079 \mathrm{MWh}$ (at PF-1) or, in 2009, that amounted to around $88 \%$ and $41 \%$ of the total electricity which consumed by households in Tanjung Jabung Timur district and in the Kutai Barat district, respectively (Table 2). This 12,079 MWh electricity production will also satisfy around $66 \%$ and $37 \%$ of total electricity consumption at the two districts respectively.

If the comparison were made for the total electricity delivered at the provincial level (Table 2), the following summaries would be possible: (1) around 3\% of total household demand for electricity could be satisfied at the district level in both of the two provinces (2) around 2-3\% total households consumption of electricity could be met at
Jambi and East Kalimantan provinces, respectively. In this scenario, the net carbon emissions avoided will vary from 323 to $8,503 \mathrm{Mg}$ when substituting biomethanol for natural gas-methanol in a fuel cell and from 294 to $7,730 \mathrm{Mg}$ when biomethanol is used to supplement gasoline consumption.

If all forest biomasses from both PF-1 and PF-2 were harvested and converted to biomethanol, the following results are possible (from Figure 6): (1) each year 127,867 households could receive electricity continuously using a $1 \mathrm{~kW}$ fuel cell. If the average household size in Indonesia is 4.15 persons [50], this efficiency of converting biomass to biomethanol would allow 19\% of the households in Jambi province and $248 \%$ of Tanjung Jabung Timur district to be supplied with electricity using fuel cells; (2) If biomethanol is substituted for fossil fuels to produce electricity with fuel cells, from $187-375 \%$ of the electricity demand in Jambi province could be satisfied from biomass harvested from PF-1. In comparison, PF-2 would satisfy $142-285 \%$ of the electricity demand; (3) Collecting all the biomass from either PF-1 or PF-2 and converting it to biomethanol for use as a gasoline substitute would be sufficient to meet all the gasoline consumed in Jambi in 2009; (4) in addition, surplus biomethanol would be available for other uses.

According to Dewan Nasional Perubahan Iklim/DNPI or the National Council for Climate Change (NCCC) of Indonesia, Jambi province emitted 57 million $\mathrm{Mg}$ of carbon in 2005 and is projected to emit 74 million tons by 2030 [51]. In its published report, Asian Pulp and Paper (APP), a holding company mentioned that their GHG emissions were $6,416,058 \mathrm{Mg} \mathrm{CO}_{2} \mathrm{e}$ in 2006 [52]. The same report stated that the company: (1) imported about 2,666 Terra Joule (TJ) of electricity; (2) consumed about 76,204 TJ of fossil fuels at both their stationary and mobile combustion units. Although the overall findings of this report have been criticized as not representing the total carbon footprint of the company [53], they can still be used to compare the magnitude of biomethanol that would be needed by this company for it to significantly decrease its carbon emissions.

In APP case, the amounts of carbon emissions avoided when using biomethanol to produce electricity and as a gasoline substitute are summarized in Figure 7. The highest reductions in carbon emissions occurred when an equivalent amount of biomethanol was used as biofuels to replace fossil fuels (gasoline) by the company. The highest reduction in 


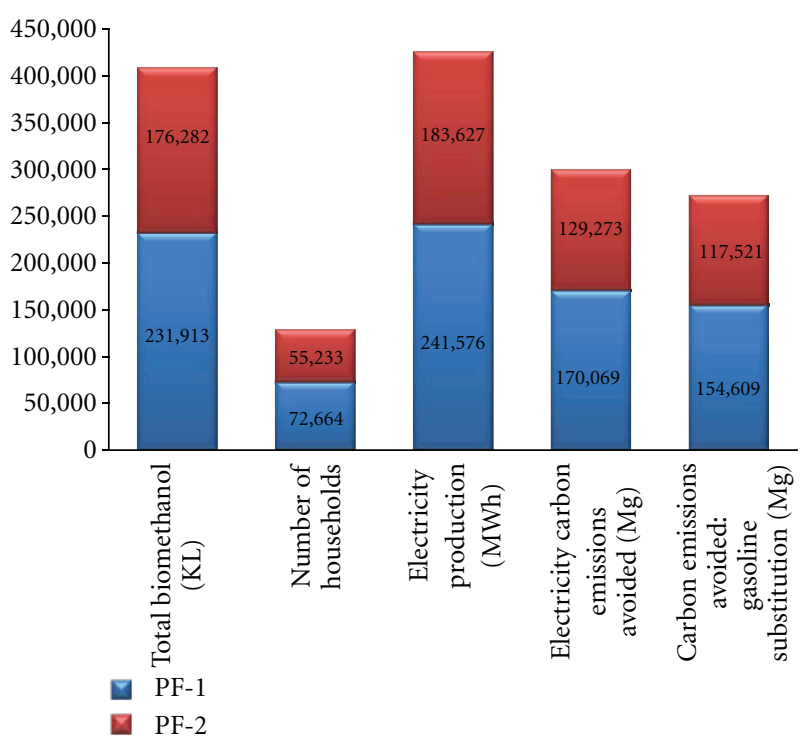

Figure 6: The amount of biomethanol produced and the amount of fossil-resource-derived electricity and gasoline, this amount can potentially replace and avoid carbon emissions when converting $100 \%$ of the annually available biomass collected from certified plantation production forests $(\mathrm{PF})$.

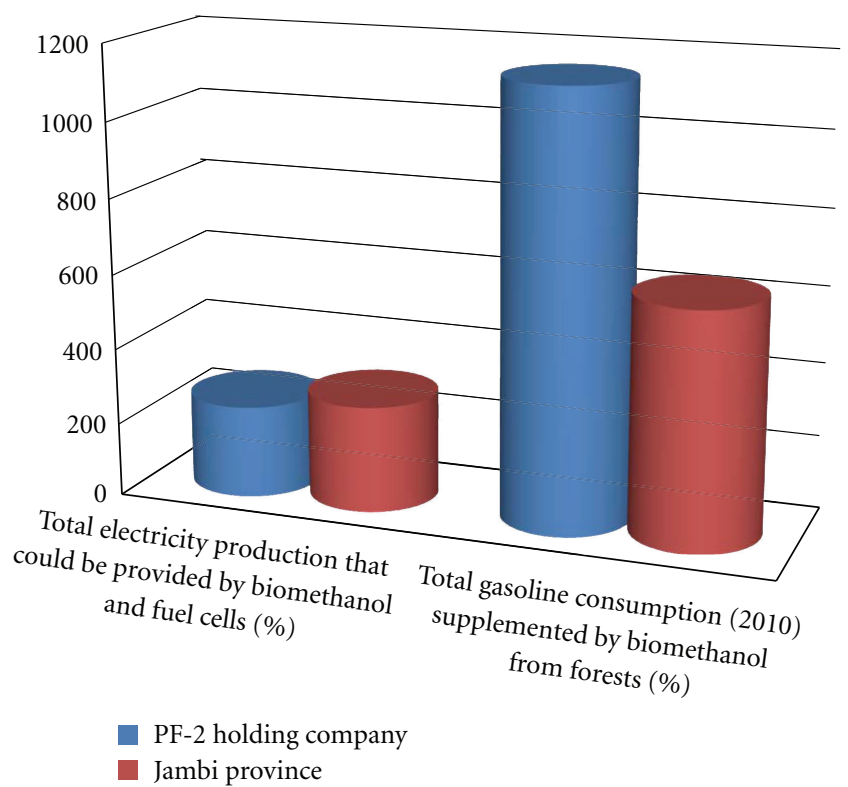

Figure 7: The Proportion APP and Jambi Province Consumption of Gasoline and Electricity Production that can be substituted by biomethanol.

carbon emissions was possible when biomethanol was used to produce electricity from fuel cells in both the company and in Jambi province.

In another scenario where all the biomasses harvested were converted to biomethanol from forests managed by APP the biomethanol would be sufficient to produce enough energy over an 11-year time period (this assumes that the annual consumption is equivalent to 2006 levels). In this situation, the carbon emissions reductions possible from using biomethanol as a substitute for fossil fuels would be: (1) 5 million $\mathrm{Mg}$ of carbon emissions avoided being emitted in 2006 either from producing electricity or from replacing gasoline with biomethanol using data from APP, and (2) around 6 million $\mathrm{Mg}$ of carbon not emitted in Jambi using 2009 data (Table 3).

Beside the above calculation (as stated in Table 3), Hasegawa et al. [39] suggested to analyze carbon dioxide emissions (instead of carbon emissions) reduction. In their study, Hasegawa et al. [39] calculated the emissions reductions from a fuel cell vehicle (FCV) that consumed M100 (neat biomethanol). For this scenario, driving a FCV reduced carbon dioxide emissions by $1,001 \mathrm{~kg}$ for every ton of forest biomass that was used to substitute for fossil fuel use [39]. If the provincial governments of East Kalimantan and Jambi required that all new vehicles use the products from this technology, available biomass from NPF-2 (East Kalimantan) and PF-2 (Jambi) would be able to reduce their carbon dioxide emissions from 45,618 to $559,626 \mathrm{Mg}$ every year, respectively.

Using wood to produce biofuels has not received as much attention as the use of agricultural crops or grasses. This is a result of economic analyses conducted during the early 1990's that indicated that the conversion of wood biomass to methanol was more expensive than using natural gas as a feedstock [22, 54]. However, several new factors are suggesting that the past economic analyses are less relevant in today's landscape. Biomethanol production is now competitive with methanol production from natural gas because of the economic externalities of environmental problems that include [55-57], for example: (1) the costs of forest fires due to an abundance of over-stocked forests that create high fire risks; (2) greenhouse gas emissions from using fossil fuels; (3) the societal costs of rural communities with high unemployment and insecure resource extraction environments; (4) the development of gasifiers that efficiently convert wood with up to $40 \%$ moisture contents; (5) the commercial availability of "turn-key" fuel cells running on methanol; (6) subsidies/incentives for generating energy from renewable resources; (7) the decline of oil and gas reserves in several countries; (8) the need to improve the social, economic, and ecological values derived from forest, particularly production forests.

Those factors together now make wood a competitive alternative to use in producing energy and will provide a greater diversity of economic values to forests (e.g., clean energy, "green credits," "green electricity") [58, 59]. Emissions trading and green certificates (i.e., market-based mechanisms enforced to curb greenhouse gas emissions and increase electricity production from renewable energy resources) will also increase the competitiveness and markets for biofuels compared to fossil fuels [60]. Although technologies to produce bioethanol and biomethanol from lignocellulosic biomass are still under development, according to Hasegawa et al. [39], the biomethanol production process was revealed as being preferable to the bioethanol process in terms of energy yield, carbon conversion, and the environmental burden. 
TABle 3: Proportion of $\mathrm{C}$ emissions avoided by substituting electricity generated from fuel cells using biomethanol in place of electricity generated from fossil fuels and by substituting biomethanol for gasoline consumed in transportation fuels. Assumptions: timber is converted into biomethanol at a $50 \%$ conversion efficiency.

\begin{tabular}{lcc}
\hline & $\begin{array}{c}\text { C emissions avoided by substituting biomethanol and fuel cells } \\
\text { to produce electricity relative to total produced (per-mil) }\end{array}$ & $\begin{array}{c}\text { Carbon emissions avoided by substituting biomethanol for } \\
\text { gasoline relatively to total produced (per-mil) }\end{array}$ \\
\hline $\begin{array}{l}\text { APP } \\
\text { Jambi }\end{array}$ & 0.55 & 0.50 \\
province & 0.61 & 0.59 \\
\hline
\end{tabular}

Forest concessionaires and CBFM practitioners are willing to consider planting-specific trees or simply use forest residues for bioenergy. Since the market for woody biomass for bioenergy is not yet available, particularly for CBFM and small wood industry practitioners, managing forests to produce biomass for bioenergy programs has not been considered economically viable. Additionally, there is no evidence to suggest that the economics of biofuels industry are likely to change in the foreseeable future unless the government of Indonesia reevaluates its biofuel plan and increases transparency in the development of biofuels for energy security [61].

Two principles are apparently crucial for successfully developing bioenergy, namely, flexibility (the right level of devolution depends on the resource stake and negotiation with local stakeholders) and lessons learned from projects being implemented at the local level [62]. Several pilot projects at various forest management types and locations may provide a clearer picture about how bioenergy may affect energy security at the local level, and how it will restore forest health as well as its potential to create new businesses and jobs for local people.

\section{Concluding Remark}

Adopting forest bioenergy systems is a logical solution to address the problems of reducing carbon emissions while satisfying local energy demands and developing local economies. New technology provides better options to transform forest biomass into biomethanol and subsequently using it to generate electricity or as a supplement or substitute for fossil-based transportation fuels. This study demonstrates that a significant amount of biomethanol can be produced from a certified (sustainably managed) plantation forest, particularly if all harvested biomass is dedicated for bioenergy production (energy farms). In addition, bioenergy has the potential to supply other energy requiring demands, for example, forest base camp, small industries (not necessarily related to forestry), and the needs of local communities. This form of energy production should be developed to satisfy the existing demand in most of the remote areas in Indonesia, particularly when the distribution of on-grid electricity and fossil fuels (for both producing electricity and transportation fuels) are not always available. In Indonesia, energy distribution is challenging for several reasons, for example, fuel prices, quota systems, weather, broken bridges, and land erosion. This means that many locations do not receive sufficient energy to satisfy the local demand or needs of the industries located in these areas.

Developing mobile biomethanol production systems, which could be more easily moved to forest harvesting areas or to other areas where biomass is available, would keep biomethanol production sustainable, particularly in CBFM areas. Managing forests under the sustainable rubric and/or being certified under a sustainable forest management protocol may be a necessary condition to make sure that any biomass harvested from the production forest areas does fulfill the minimum requirements capable of sustaining the function of the social, economical, and environmental aspects of the forest.

\section{Acknowledgments}

The authors are grateful for inputs and comments from Patricia Roads, Mia Siscawati as well as for tremendous research supports provided to A. Suntana by Dr. Steve Rhee of the Ford Foundation's Indonesia Office and Peter Riggs of the Climate Change that Strengthen Rural Communities Initiative, Ford Foundation.

\section{References}

[1] EIA, "Country Analysis Brief: Indonesia," U.S. Energy Information Administration, 2010, http://www.eia.doe.gov/ emeu/cabs/Indonesia/pdf.pdf.

[2] S. S. Wirawan and A. H. Tambunan, "The Current Status and Prospects of Biodiesel Development in Indonesia: A Review," in Proceedings of the 3rd Asia Biomass Workshop, National Institute of Advanced Industrial Science and Technology (AIST), Tsukuba, Japan, 2006.

[3] APEC, "APEC Energy Overview 2009," edited by K. Penney and WordsWorth_Writing, Tokyo, Japan, 2010, http://www .ieej.or.jp/aperc/2009pdf/Overview2009.pdf.

[4] R. Bacon and M. Kojima, "Coping with higher oil prices," The World Bank, Washington DC, USA, 2006, http://siteresources.worldbank.org/INTOGMC/Resources/higheroilpricesuneditedjune2006.pdf.

[5] APEC, "APEC Energy Demand and Supply Outlook 2006: Indonesia," 2006, http://www.ieej.or.jp/aperc/2006pdf/Outlook2006//ER_Indonesia.pdf.

[6] Y. N. Caruso, M. Colchester, F. Mackay, N. Holdyard, and G. Nettleton, Extracting Promises: Indigenous Peoples, Extractive Industries and the World Bank, Forest Peoples Programme \& Tebtebba Foundation, Baguio City, Philippines, 2003.

[7] J. G. Canadell and M. R. Raupach, "Managing forests for climate change mitigation," Science, vol. 320, no. 5882, pp. 1456-1457, 2008. 
[8] K. A. Vogt, M. G. Andreu, D. J. Vogt et al., "Societal values and economic return added for forest owners by linking forests to bioenergy production," Journal of Forestry, vol. 103, no. 1, pp. 21-27, 2005.

[9] K. A. Vogt, J. Honea, D. J. Vogt et al., Forests and Society: Sustainability and Life Cycles of Forests in Human Landscapes, CABI, Wallingford, UK, 2006.

[10] K. A. Vogt, D. J. Vogt, T. Patel-Weynand et al., "Bio-methanol: how energy choices in the western United States can help mitigate global climate change," Renewable Energy, vol. 34, no. 1, pp. 233-241, 2009.

[11] P. Chaturvedi, Bioenergy Resources: Planning, Production, and Utilization, Concept Publications, New Delhi, India, 1995.

[12] R. Lamb, Forest, Fuel, and the Future-Wood energy for Sustainable Development, Forestry Department, Food and Agriculture Organization of the United Nations (FAO), Rome, Italy, 1996, http://www.fao.org/docrep/v9728e/v9728e00.htm.

[13] L. Gustavsson and P. Svenningsson, "Substituting fossil fuels with biomass," Energy Conversion and Management, vol. 37, no. 6-8, pp. 1211-1216, 1996.

[14] A. S. Suntana, K. A. Vogt, E. C. Turnblom, and R. Upadhye, "Bio-methanol potential in Indonesia: forest biomass as a source of bio-energy that reduces carbon emissions," Applied Energy, vol. 86, supplement 1, pp. S215-S221, 2009.

[15] K. S. Jagadish, "Bioenergy for India: prospects, problems and tasks," Energy for Sustainable Development, vol. 7, no. 1, pp. 28-34, 2003.

[16] J. Richardson, R. Bjorheden, P. Hakkila, A. T. Lowe, and C. T. Smith, Bioenergy from Sustainable Forestry: Guiding Principles and Practice, Kluwer Academic, Boston, Mass, USA, 2002.

[17] N. Moreira, "Growing expectation: new technology could turn fuel into a bumper crop," News Science, vol. 168, no. 14, pp. 218-220, 2005.

[18] N. Greene, "Growing energy: how biofuels can help end America's oil dependence," Natural Resources Defense Council, Washington DC, USA, 2004, http://www.nrdc.org/air/energy/ biofuels/biofuels.pdf.

[19] B. Amigun, J. Gorgens, and H. Knoetze, "Biomethanol production from gassification of non-woody plant in South Africa: optimum scale and economic performance," Energy Policy, vol. 38, pp. 312-322, 2010.

[20] D. Edlund, "Fuel Cells: An Emerging Option for Small-Scale Distributed Generation," EGSA Powerline Idatech, LLC, 1999, http://www.idatech.com/technology/publications/fc_ powerline_story.pdf.

[21] M. Ohlström, T. Makinen, J. Laurikko, and R. Pipatti, "New concepts for biofuels in transportation: biomass-based methanol production and reduced emissions in advanced vehicles," Espoo, VTT (Technical Research Centre of Finland) Energy. VTT Research Note, 2001, http://www.vtt.fi/inf/pdf/ tiedotteet/2001/T2074.pdf.

[22] S. Gust and J. P. Nieminen, "Liquefied Wood Fuel could Soon Replace Heavy Oil," Wood Energy, 2002, http://www.itebe .org/telechargement/revue/Revue6/Revue6-fuels-EN.pdf.

[23] B. Lemley, "Anything into oil. Technological savvy could turn 600 million tons of turkey guts and other waste into 4 billion barrels of light Texas crude each year," Discover, vol. 24, no. 5, 2003.

[24] F. O. Wärtsilä, "Bioenergy Solutions from Wärtsilä,” Wärtsilä Finland Oy, Helsinki, Finland, 2007, http://www .greennetfinland.fi/fi/images/3/32/R\%C3\%A4ty_120905.pdf.

[25] H. Nakagawa, T. Harada, T. Ichinose et al., "Biomethanol production and $\mathrm{CO}_{2}$ emissionreduction from forage grasses, trees, and crop residues," Japan Agricultural Research Quarterly, vol. 41, no. 2, pp. 173-180, 2007.

[26] N. El Bassam, Energy Plant Species: Their Use and Impact on Environment and Development, James \& James (Science Publishers), London, UK, 1998.

[27] H. S. Kheshgi, R. C. Prince, and G. Marland, "The potential of biomass fuels in the context of global climate change: focus on transportation fuels," Annual Review of Energy and the Environment, vol. 25, pp. 199-244, 2000.

[28] R. L. Edmonds, J. K. Agee, and R. L. Gara, Forest Health and Protection, McGraw-Hill, Boston, Mass, USA, 2000.

[29] H. Indrabudi, L. R. Wardoyo, and A. Siregar, Global Forest Resources Assessment 2010: Indonesia Country Report. M. Wilkie, FAO, Rome, Italy, 2010, http://www.fao.org/forestry/ 20350-20059fec20353a20359e20354ff20452eb269646321c269646696f.pdf.

[30] International Tropical Timber Organization (ITTO), Status of Tropical Forest Management 2005, ITTO technical series, no. 24, International Tropical Timber Organization (ITTO), Yokohama, Japan, 2006, http://www.itto.int/sfm_detail/id $=1801$.

[31] Asosiasi Pengusaha Hutan Indonesia (APHI), "Daftar anggota APHI 2006-2011,” APHI (Asosiasi Pengusaha Hutan Indonesia)/Indonesian Forest Concession Holders Association), 2010.

[32] H. Kartodihardjo and A. Supriono, The Impact of Sectoral Development on Natural Forest Conversion and Degradation: The Case of Timber and Tree Crop Plantations in Indonesia, Center for International Forestry Research, Bogor, Indonesia, 2000.

[33] Awang S. A., Dekonstruksi Kehutanan Sosial: Reposisi Masyarakat dan Keadilan Lingkungan, Bigraf Publication \& Program Pustaka, Yogyakarta, Indonesia, 2004.

[34] U. Hasanuddin and A. Haryanto, (personal communication, November 2011).

[35] Official Journal of the European Union, "Directive 2009/ 30/EC of the European parliament and of the council of 23 April 2009," 2009, http://eur-lex.europa.eu/LexUriServ/ LexUriServ.do?uri=OJ:L:2009:140:0088:0113:EN:PDF.

[36] C. N. Hamelinck and A. P. C. Faaij, "Future prospects for production of methanol and hydrogen from biomass," Journal of Power Sources, vol. 111, no. 1, pp. 1-22, 2002.

[37] R. A. Perry and D. W. Green, Perry's Chemical Engineers' Handbook, McGraw-Hill, New York, NY, USA, 1984.

[38] T. B. Reed and R. M. Lerner, "Methanol: a versatile fuel for immediate use," Science, vol. 182, no. 4119, pp. 1299-1304, 1973.

[39] F. Hasegawa, S. Yokoyama, and K. Imou, "Methanol or ethanol produced from woody biomass: which is more advantageous?" Bioresource Technology, vol. 101, no. 1, supplement, pp. S109S111, 2010.

[40] J. Schindler, R. Wurster, M. Zerta, V. Blandow, and W. Zittel, "Where will the energy for hydrogen production come from? Status and alternatives," European Hydrogen Association (EHA), 2006, http://www.lbst.de/publictations/ studies_e/2007/EHA_WhereWillH2ComeFrom_2007.pdf.

[41] A. Field, Discovering statistics using SPSS, Sage, London, UK, 2005.

[42] G. W. Oehlert, A First Course in Design and Analysis of Experiments, W. H. Freeman, New York, NY, USA, 2000.

[43] Lembaga Ekolabel Indonesia (LEI), "Naskah akademis: sistem sertifikasi pengelolaan hutan berbasis masyarakat lestari 
(PHBML)," Document Number LEI-V/NA LEI-03, Lembaga Ekolabel Indonesia (LEI), 2002.

[44] I. Kurniawan and J. M. Roshetko, "Market's risk and production uncertainty: drivers of agroforestry land use diversification of smallholders teak grower in Gunungkidul district, Indonesia," in Proceedings of the 2nd World Congress of Agroforestry, World Agroforestry Center and Winrock International, Nairobi, Kenya, 2009.

[45] A. Hinrichs, D. Muhtaman, and N. Irianto, Forest Certification on Community Land in Indonesia, GTZ GmbH, Jakarta, Indonesia, 2008.

[46] C. Heruela, "Wood energy information and analysis for sustainable forest management: linking national and international efforts in South and Southeast Asia," EC-FAO Partnership Programme (2000-2002), Bangkok, Thailand, 2000, $\mathrm{ftp}: / / \mathrm{ftp}$.fao.org/docrep/fao/003/X6638E/X6638E00.pdf .

[47] R. B. Hiremath, B. Kumar, P. Balachandra, N. H. Ravindranath, and B. N. Raghunandan, "Decentralised renewable energy: scope, relevance and applications in the Indian context," Energy for Sustainable Development, vol. 13, no. 1, pp. 4-10, 2009.

[48] BPS-Jambi, "Jambi dalam angka (Jambi in figures)," Badan Pusat Statistik Provinsi Jambi, Jambi, Indonesia, 2010, http:// www.jambiprov.go.id/download/jda2010_bab4.pdf.

[49] BPS-Kalimantan Timur, "Kalimantan Timur dalam angka (Kalimantan Timur in figures)," Badan Pusat Statistik Kalimantan Timur, Samarinda, Indonesia, 2010, http://kaltim.bps .go.id/?p=106.

[50] S. Adioetomo, T. Djutaharta, and Hendratno, "Cigarette consumption, taxation, and household income: Indonesia case study," Heatlh, Nutrition, and Population (HNP), World Bank's Human Development Network, 2005.

[51] Tempo Interaktif, "Jambi turunkan emisi karbon 70 juta ton," 2010, http://www.tempointeraktif.com/hg/iptek/2010/04/13/ brk,20100413-240000,id.html.

[52] Environmental Resources Management (ERM), "Asia Pulp \& Paper-Indonesia: executive summary of APP's carbon footprint assessment," Environmental Resources Management (ERM), 2008, http://www.cathay.com.br/pt/ARQUIVOS/pdf/ informes/programa-Carbon-Foot-Print.pdf.

[53] B. Barclay and T. Kawakami, "Asia Pulp \& Paper hidden emissions: calculating the real carbon footprint of APP's paper," Rainforest Asian Network (RAN) and Japan Tropical Forest Action Network (JATAN), Tokyo, Japan, 2010, http://ran.org/content/asia-pulp-papers-hidden-emissions-0.

[54] R. A. Sedjo, "The economics of forest-based biomass supply," Energy Policy, vol. 25, no. 6, pp. 559-566, 1997.

[55] AMI, "Beyond the Internal Combustion Engine. The Promise of Methanol Fuel Cell Vehicles," 2003, http://www.methanol .org/Energy/Resources/Fuel-Cells/MI-Promise-Report.aspx.

[56] USFS, "A strategic assessment of forest biomass and fuel reduction treatments in Western States," General Technical Report RMRS-GTR-149, U.S. Department of Agriculture, Forest Service, Rocky Mountain Research Station, Fort Collins, Colo, USA, 2005, Prepared by Rummer, B. J. Prestemon, D. May, P. Miles, J. Vissage, R. McRoberts, G. Liknes, W.D. Shepperd, D. Ferguson, W. Elliot, S. Miller, S. Reutebuch, J. Barbour, J. Fried, B. Stokes, E. Bilek, and K. Skog, http://www .fs.fed.us/rm/pubs/rmrs_gtr149.pdf.

[57] QLG, "Northeastern California ethanol manufacturing feasibility study," Quincy Library Group, California Energy Commission, California Institute of Food and Agricultural Research, Plumas Corporation, TSS Consultant, National
Renewable Energy Laboratory (U.S.), 1997, http://www.qlg .org/pub/act_acp/ethanol/feasibility.htm.

[58] J. Luukkanen, "Green paper with green electricity? Greening strategies of Nordic pulp and paper industry," Energy Policy, vol. 31, no. 7, pp. 641-655, 2003.

[59] L. Nielsen and T. Jeppesen, "Tradable Green Certificates in selected European countries-overview and assessment," Energy Policy, vol. 31, no. 1, pp. 3-14, 2003.

[60] J. Ruokonen, "Trading: how to optimize when active in both markets," in Proceedings of the International Nording Bioenergy Conference, Jyväskylä, Finland, month year.

[61] H. S. Dillon, T. Laan, and H. S. Dillon, Biofuel-At What Cost? Government Support for Ethanol and Biodiesel in Indonesia, The Global Subsidies Initiative (GSI) of the International Institute for Sustainable Development (IISD), Geneva, Switzerland, 2008, http://www.iisd.org/gsi/sites/default/files/ indonesia_biofuels.pdf.

[62] O. Dubois, "Making sure that biofuel development benefits small farmers and communities," in Land Use, vol. 59, A. Perlis, Ed., Unasylva, no. 230, pp. 25-32, 2008, ftp://ftp.fao.org/ docrep/fao/011/i0440e/i0440e00.pdf. 

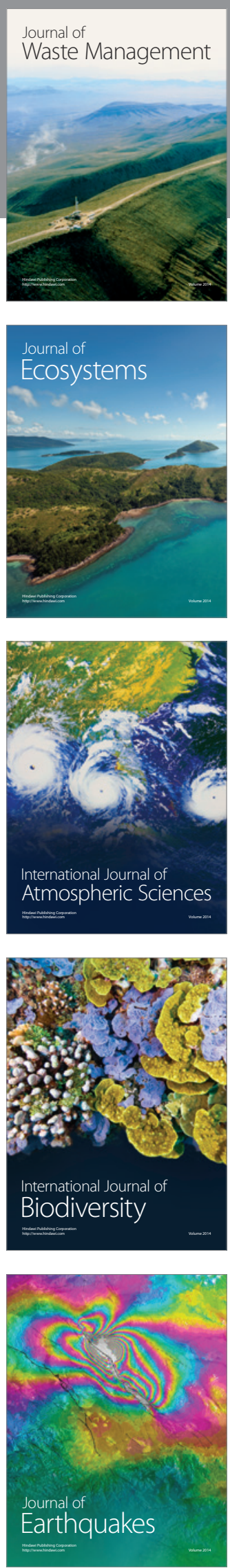
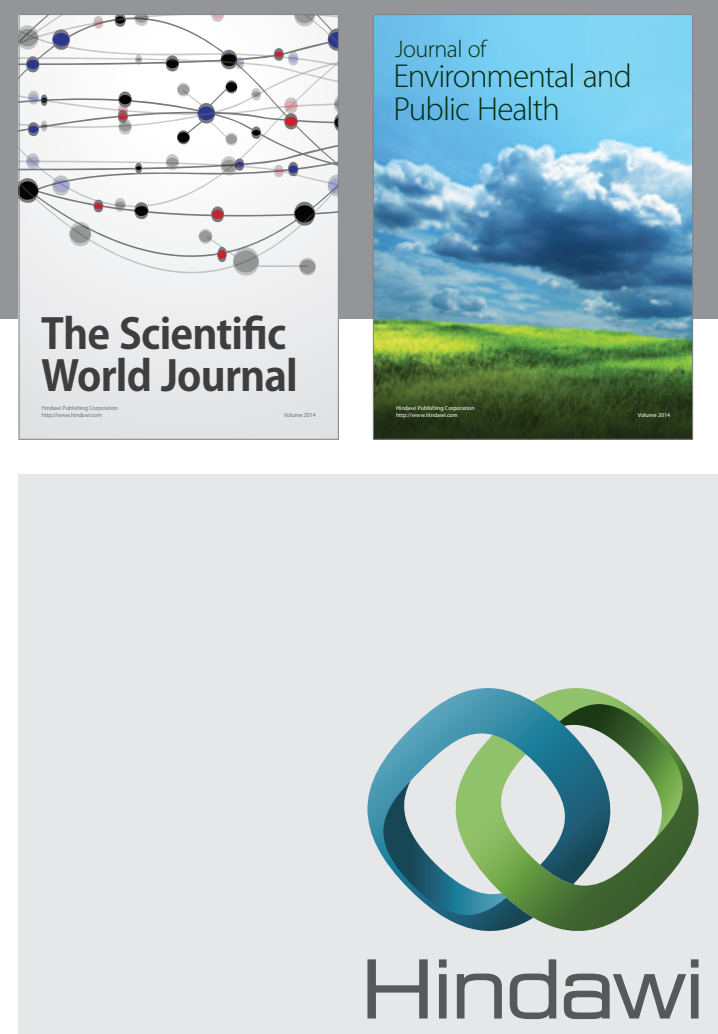

Submit your manuscripts at

http://www.hindawi.com
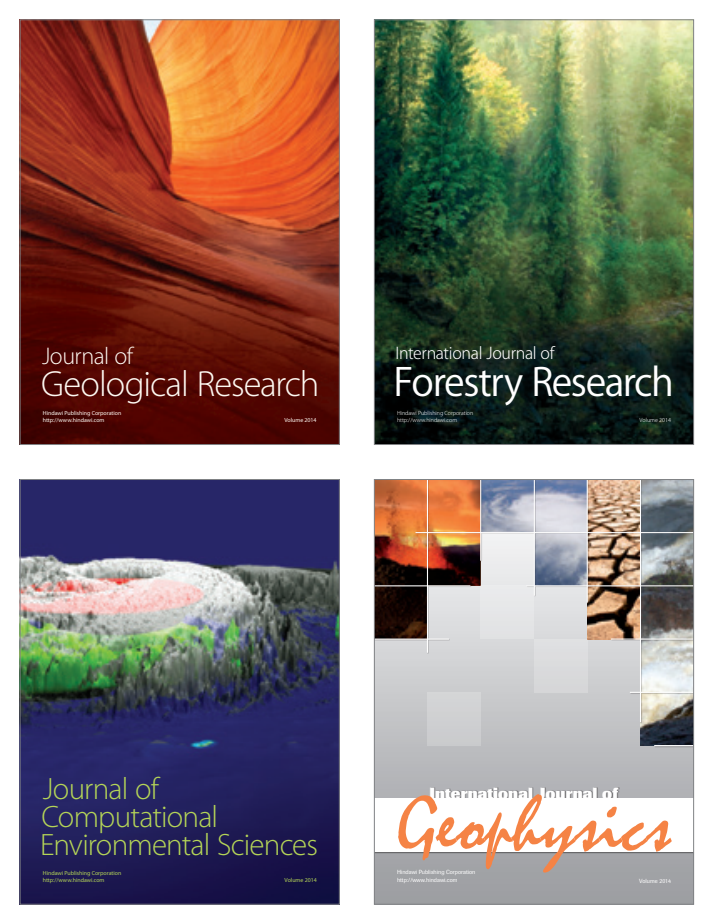
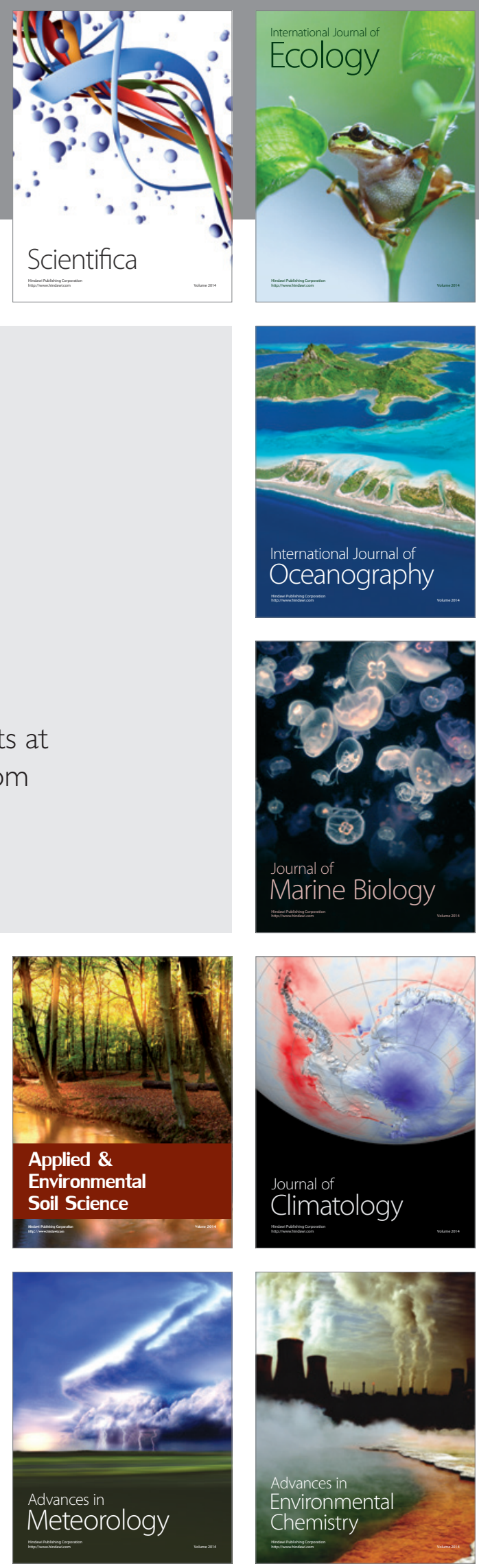